\title{
尿中ヨウ素排泄濃度の個人内・個人間変動
}

\author{
久田文, 鈴木 弥生, 吉永 淳 \\ 東京大学大学院新領域創成科学研究科
}

\section{Intra- and Inter-individual Variation in Urinary Iodine Concentration}

\author{
Aya HISADA, Yayoi SUZUKI and Jun YOSHINAGA \\ Department of Environmental Studies, University of Tokyo
}

\begin{abstract}
Objectives: To quantitatively assess the intra- and inter-individual variation of urinary iodine concentration in Japanese to determine whether urinary analysis is applicable to assessing habitual iodine intake in subjects on an individual basis.

Methods: Five urine samples (first void) were taken from each of the 14 healthy female subjects at 2-3 week intervals over 4-5 months. Information on diet and medication use on the previous day of urine sampling was obtained by a questionnaire during each urine sampling. The concentration of iodine in urine samples was measured by inductively coupled plasma mass spectrometry (ICP-MS). Intra- and interindividual variation was assessed by intra class correlation coefficient (ICC).

Results: The median concentration of iodine in 70 urine samples was $91 \mu \mathrm{g} / \mathrm{g}$-cre (range: $15-4400$ $\mu \mathrm{g} / \mathrm{g}$-cre). The mean iodine concentration in urine samples from subjects who took iodine-rich foods/ medications on the day before sampling was statistically significantly higher than that from subjects who did not take such foods/medications $(p<0.01$, t-test). The ICC of urinary iodine concentration of the 14 subjects was 0.55 , indicating good reproducibility; however, this was 0.28 when one subject who routinely used an iodine-containing gargle was excluded from analysis.

Conclusions: Urine sampled on a single occasion is not a suitable medium for the assessment of longterm intake levels of iodine in subjects on an individual basis.
\end{abstract}

Key words: iodine (ヨウ素), biomarker (バイオマーカー), urine (尿), Japanese (日本人)

はじめに

ヨウ素は甲状腺ホルモン生成に欠かせない微量栄養素 であり，ヨウ素摂取欠乏により甲状腺機能に影響をきた すことは広く知られている(1)。ヨウ素欠乏状態では甲 状腺腫や甲状腺ホルモン生成の低下による甲状腺機能低 下症やクレチン症などを引き起こす (2)。特に, 妊娠期 の母親のヨウ素栄養は胎児の発育にも非常に重要であ る。妊娠期には軽度・中度のヨウ素欠乏であっても胎児 の発達や知能発育などに影響を及ぼす $(3,4)$ 。一方， ヨ ウ素過剰によっても甲状腺機能に影響が生じる $(5,6)$ 。 ヨウ素過剰摂取の妊婦に扣いて出生児の甲状腺機能低

受付 2011 年 4 月 4 日, 受理 2011 年 6 月 29 日

Reprint requests to: Jun YOSHINAGA

Department of Environmental Studies, University of Tokyo, Kashiwanoha 5-1-5, Kashiwa, Chiba 277-8563, Japan

TEL/FAX: +81(4)7136-4716

E-mail: junyosh@k.u-tokyo.ac.jp
下等の影響が報告されている（7）。こうしたことから， WHO では, ヨウ素欠乏地域の妊婦のヨウ素摂取を推奨す る一方, 過剰摂取についても注意喚起をしており（5）, 日 本では, 2010 年に日本人の成人男女の耐容上限量は $2,200 \mu \mathrm{g} /$ 日と設定された (8)。

われわれは, 環境化学物質曝露による妊婦の甲状腺機 能への影響を介した小児発達影響を調査中であり，母体 の甲状腺機能ならびに小児の発達に影響する可能性のあ る母親のヨウ素摂取状況を共変量として調査に取りこむ ことを計画している。そこで，母親のヨウ素摂取指標と してスポット尿や早朝尿などの尿中ヨウ素濃度に注目し た。尿中ヨウ素濃度は, 短期間のヨウ素摂取量を反映す る指標として諸外国でも広く用いられている指標であり (1)，とくにスポット尿や早朝尿による調査は簡便かつ非 侵襲的であることから, 疫学調査に適した手法と考光ら れる。しかし，ヨウ素の代謝が早いことや，ヨウ素は特 定の食品群に高濃度で偏在していることから，個人内で のヨウ素摂取量・排泄量の変動が大きいことが予想され 
る。一方で, 個人の㒂好等により, 個人間でヨウ素摄取 量・排泄量に大きな差が存在する可能性がある。Busnardo らは，ヨウ素摂取の十分な地域に执いて，スポット尿に よるヨウ素排泄量の個人内変動拈よび個人間変動を調查 し，個人内変動は，個人間変動に比べ小さいことを示し た。さらにこの要因として，ヨウ素を含む食品の日常的 な摂取頻度の個人差が関わることを示唆している (9)。 日本人の摂取する食物には海藻などのヨウ素を高濃度に 含有するものが多くあることから，そうした食品を摄取 する習慣のない国・地域の人々とは尿中ヨウ素排泄濃度 の個人内・個人間変動パターンが大きく異なる可能性が ある。以上のことから，尿試料を用いて個人のヨウ素の 長期摂取傾向を評価することの可能性を検討するにあ たっては, 個人内変動と個人間変動の定量的な比較が必 要であるが，これまでわが国に打いて，そのような検討 を行った例はない。

近年のバイオマーカーを用いた化学物質曝露評価の分 野では, 生物学的半隇期の短い化学物質について, スポッ 卜尿や早朝尿を用いて個人レベルでの慢性暴露評価を行 らことの妥当性に関して定量的な検討が行われるよらに なった。これは, 同一対象者から繰り返し採尿し, 目的 化学物質の測定より得られた排泄濃度の級内相関係数 (ICC: Intraclass correlation coefficient）を用いて，個人内 変動・個人間変動の相対的関係を定量的に検討するもの である。その結果, 半隇期が一日以内の代謝が早い物質 についても，スポット尿中濃度はある一定期間の曝露レ ベルの傾向を反映することが報告されている $(10,11)$ 。

そこで本研究では，尿中ヨウ素濃度の個人内・個人間 变動を, ICCを用いて定量的に比較・評価し，早朝尿中ヨ ウ素排泄濃度の適用性をあらためて検討することとした。

\section{方法}

\section{対象とサンプリング}

20 歳から 37 歳までの妊娠可能年齢にある日本人女性 (平均土標準偏差 : $25 \pm 5$ 歳) で, 本研究に関する説明文 書を配布し, 書面にて研究への参加の同意が得られた 14 名を対象者とした（Table 1)。対象者には 2009 年 7 月 から 2010 年 1 月までに約 3 週間（20.1 $1 \pm 7.3$ 日）ごとに 5 回, 早朝尿のサンプリングおよび質問票への回答を依 頼した。事前にサンプリング用尿カップと $100 \mathrm{~mL}$ ポリプ ロピレン製ボトル，質問票を対象者に配布し，期間中に 採取された早朝尿をクールボックスにいれてもらい質問 票とともに回収した。回収した尿は直ちに $15 \mathrm{~mL}$ ポリプ ロピレン製スピッッに分注し， $-20^{\circ} \mathrm{C}$ で冷凍保存した。 質問票では 5 回のサンプリングごとに前日の食事内容と 医薬品の使用について回答してもらい，さらに初回サン プリング時の久年齢，身長，体重等の基本情報と日常的 な食物の嗜好飞ついて子回答を得た。前日の食事内容に ついての回答から, 以下の基準で「ヨウ素を高濃度に含 むと考光られる食品等」を選定した：(1)日本食品標準成
Table 1 Attribute of subjects

\begin{tabular}{ll}
\hline Subject & 14 Japanese women \\
Age $($ mean \pm SD) & $24.5 \pm 4.3$ years \\
Sampling period & $2009 / 7 / 27-2010 / 1 / 4$ \\
Sampling interval (mean \pm SD) & $20.1 \pm 7.3$ days \\
\hline
\end{tabular}

Table 2 Operation parameters of ICP-MS for the measurements of urinary iodine concentration

\begin{tabular}{lc}
\hline Instrument & Agilent $7500 \mathrm{ce}$ \\
RF power & $1500 \mathrm{~W}$ \\
Plasma gas (Ar) flow rate & $15 \mathrm{~L} / \mathrm{min}$ \\
Carrier gas (Ar) flow rate & $0.86 \mathrm{~L} / \mathrm{min}$ \\
Makeup gas (Ar) flow rate & $0.55 \mathrm{~L} / \mathrm{min}$ \\
Data acquisition & $3 \mathrm{points} / \mathrm{mass}$ \\
Dwell time & $0.1 \mathrm{sec} /$ point \\
Integration time & $0.3 \mathrm{sec} / \mathrm{mass}$ \\
Repetition & 3 \\
Monitored m/z & \\
$\quad$ Iodine & 127 \\
Internal standard (Tellurium) & 130 \\
\hline
\end{tabular}

分表 (12) で公表されている食品のヨウ素濃度をもとに 求めた分布の 95 パーセンタイル以上となる, ヨウ素濃度 が $120 \mu \mathrm{g} / 100 \mathrm{~g}$ 以上の食品 (494 品目中 24 品目), および, (2)ヨウ素を高濃度で含むことが判明している医薬品，(3) 国内の病院等で甲状腺疾患の患者を対象とした摂取制限 食品として記載されている食品（赤色人工着色料使用食 品, 海藻エキス等含有の飲料水等), とした。採尿器具と して用いたポリプロピレン製ボトル，ポリプロピレン製 スピッッはいずれも中性洗剤で洗浄後, $3 \mathrm{~mol} / \mathrm{L}$ 硝酸に 3 日浸漬したのち，超純水です寸ぎ，乾燥させた後，メ タノールで洗浄したものを使用した。

\section{方法}

尿試料は $5^{\circ} \mathrm{C}$ にて解凍・混和後, $200 \mu \mathrm{L}$ をポリプロピ レン製スピッツ管にとり，100 ppbテルル内部標準液を $100 \mu \mathrm{L}, 25 \%$ 水酸化テトラメチルアンモニウム水溶液 （TAMAPURE-AA TMAH，多摩化学工業（株），川崎）を $10 \mu \mathrm{L}$ 加光，さらに超純水（MQ）で $10 \mathrm{~mL}$ までメスアッ プした。これをよく㩭拌した上で，ポリプロピレン製注 射筒に $0.45 \mu \mathrm{m}$ シリンジフィルター（Minisart; Sartorius Stedim Biotech, Goettingen, Germany）を取り付け，これに 尿試料を通してろ過し，分析試料とした。

ヨウ素濃度の測定には, 誘導結合プラズマ質量分析計

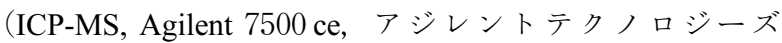
ジャパン，東京）を用いて内部標準法で定量した。ICPMS の測定条件を Table 2 に示す。

本研究に打寻ウ素の検出下限（ブランクシグナル の $3 \mathrm{SD}$ から算出）は $0.062 \mathrm{ng} / \mathrm{g}$ で，尿中濃度に換算する と $3 \mu \mathrm{g} / \mathrm{L}$ であった。また， $5 \mathrm{ng} / \mathrm{g}$ 標準液の繰り返し測定 による併行精度は相対標準偏差（RSD，\%）で表すと 
3. 9-7.4\%であった。Seronorm Urine Blank（SERO AS， Billingstad, Norway）を用いて測定真度・精度が良好であ ることを確認した（本測定值 $144 \pm 3 \mu \mathrm{g} / \mathrm{L}, \mathrm{n}=3$, 認証值 $131-147 \mu \mathrm{g} / \mathrm{L})$ 。

尿中ヨウ素濃度はクレアチニン濃度を用いて尿量補正 を行った。クレアチニン濃度測定には, クレアチニンテ ストワコー（和光純薬工業（株）, 大阪）を用い, Jaffe 法に基づき行った（13）。

統計解析にはSPSS ver. 12Jを用いた。クレアチニン補 正した尿中ヨウ素濃度を対数変換したのち, 個人内 ・個 人間分散値については，一元配置分散分析により算出し た。なお，ICC の算出には， Rosnerらのランダムモデル （式1）を用いた（14）。

$$
\mathrm{ICC}=\text { 個人間分散 } /(\text { 個人間分散 }+ \text { 個人内分散 }) （ \text { 式 } 1)
$$

な扮本研究は東京大学に打ける倫理審査を受け，承認 されたものである。

\section{結 果}

\section{尿中ヨウ素濃度}

対象者 14 名 5 回分の尿中ヨウ素濃度 $(n=70)$ の濃度 範囲は $15-4,400 \mu \mathrm{g} / \mathrm{g}$-cre，中央值は $91 \mu \mathrm{g} / \mathrm{g}$-cre であった。 ヒストグラムをFig. 1 に示す。濃度分布は対数正規分布 型であると判断した（Shapiro-Wilk test, $\mathrm{p}<0.05 ） 。$

\section{ヨウ素の摂取傾向と尿中ヨウ素濃度}

「ヨウ素を高濃度に含むと考えられる食品等」を摂取し た翌日にサンプリングしたのは，70 サンプル（5サンプ ル× 14 名）中 36 サンプルであった。また， 5 回のサンプ リング全てで前日に「ヨウ素を高濃度に含むと考えられ る食品等」を摂取していたのは 1 名であった。なお，対 象者のらち 5 回分の尿中ヨウ素濃度がすべて非常に高い 対象者が 1 名いた。以上の結果を踏ま光, 全ての尿試料 について，サンプリング前日に「ヨウ素を高濃度に含む と考えられる食品等」を摂取した場合 $(\mathrm{n}=36)$ と摂取し なかった場合 $(n=34)$ での翌日の早朝尿中ヨウ素濃度を 比較したところ，前日に「ヨウ素を高濃度に含むと考え られる食品等」を摂取した場合の濃度は有意に高かった $(\mathrm{p}<0.01$, t-test）（Fig. 2)。この傾向は，ヨウ素を含む医 薬品（らがい薬）を使用していた対象者 1 名（5サンプ ル）を除く 13 名（65サンプル）についても同様であっ た $(\mathrm{p}<0.01, \mathrm{t}$-test $)$ 。

\section{個人内・個人間変動}

本研究対象者 14 名の尿中ヨウ素濃度の採取回ごとの 傾向を Fig. 3 に示した。また，14名の対象者について， 各人 5 つの尿中ヨウ素濃度の平均值と標準偏差から, 個 人内変動を変動係数として求めたところ, 平均值は $67 \%$ （21-175\%, n=14）であったのに対し, この 14 名の尿中

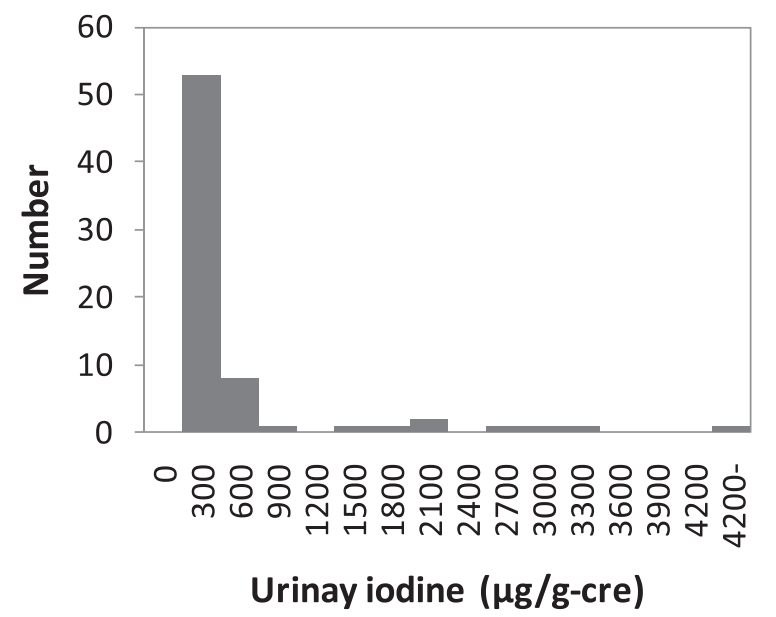

Fig. 1 Histogram of iodine concentrations in urine samples $(\mathbf{n}=\mathbf{7 0})$.

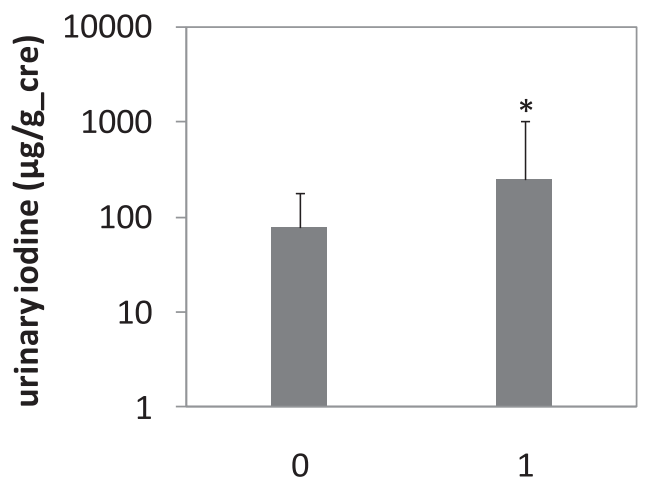

Fig. 2 Comparison of iodine concentrations in urine from subjects who took iodine-rich diet/medication on the day before sampling (1) and who did not (0). Error bars indicate geometric standard deviation. *Significantly different from control value $(0)$, $\mathrm{p}<0.01$, t-test.

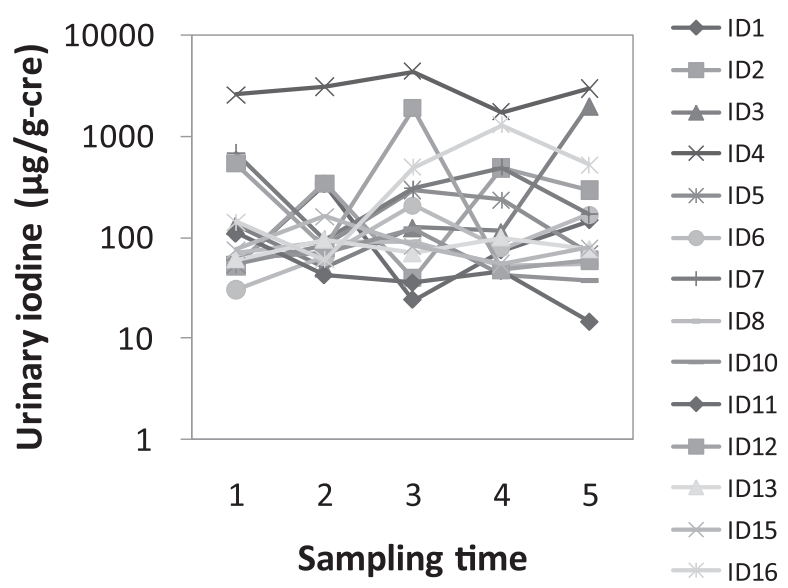

Fig. 3 Variation of iodine concentration in urine samples by subjects $(n=14)$.

ヨウ素濃度平均值 $(\mathrm{n}=5)$ の平均值と標準偏差から求め

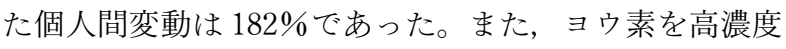
に含むらがい薬常用者（ID4）を除く 13 名では，個人内 
日衛誌 (Jpn. J. Hyg.) 第 66 巻 第 4 号 2011 年 9 月

Table 3 ICC of urinary iodine concentration

\begin{tabular}{lcc}
\hline & $\mathrm{n}=14$ & $\mathrm{n}=13^{\mathrm{a}}$ \\
\hline $\mathrm{GM}^{\mathrm{b}}$ concentration $(\mu \mathrm{g} / \mathrm{g}$-cre $)$ & 140 & 110 \\
$95 \% \mathrm{CI}(\mu \mathrm{g} / \mathrm{g}$-cre $)$ & $33-2,800$ & $32-1,100$ \\
Intraindividual variance $^{\mathrm{c}}$ & 0.017 & 0.018 \\
Interindividual variance $^{\mathrm{c}}$ & 0.021 & 0.007 \\
ICC & 0.55 & 0.28 \\
\hline
\end{tabular}

${ }^{a}$ ID4 subject who used iodine-containing gargle was excluded. ${ }^{\mathrm{b}} \mathrm{GM}$ : geometric mean.

c Analysis by one way-ANOVA after log-transformation

変動が $72 \%(21-175 \%)$ ，個人間変動が $83 \%$ であた。 また，対象者それぞれから 10-39 日間隔で 5 回採取さ れた早朝尿を用いて, 個人内個人間変動を評価するため, 一元配置分散分析により求めた個人内分散值, 個人間分 散值を用いて ICC を算出した。ICC の算出は，らがい薬 によるヨウ素の過剰摂取が疑われる対象者を含む 14 名 についてと, 過剩摂取が疑われる1名を除く 13 名につい て別々に評価を行った。その結果, 全 14 名についての ICC は0.55 であった（Table 3)。また，らがい薬の使用に よるヨウ素のレベルが高かった 1 名の対象者を除く 13 名では ICC=0.28であった（Table 3）。

\section{考察}

本研究の対象者の尿中ヨウ素濃度は, 中央值が 91 $\mu \mathrm{g} / \mathrm{g}$-cre（幾何平均：140 $\mu \mathrm{g} / \mathrm{g}$-cre, 95\%信頼区間（CI）: 33-2800）であり，日本国内で妊婦を対象として Orito ら（15）が報告した尿中ヨウ素レベル（中央值 : 259.5 $\mu \mathrm{g} / \mathrm{g}$-cre, 95\% CI : 16. 0-5353) やアメリカの大規模調査 （NHANES 2001-2002）（16）で報告されている尿中ヨウ 素濃度（中央值 : 151. $4 \mu \mathrm{g} / \mathrm{g}$-cre, 95\% CI : 142. 2-164.3） と比較すると, 中央值はやや低い值であった。これは, Oritoらや, NHANES の調査にくらべ, サンプル数が少な かったため, 代表性が不足し, 低めに偏った可能性があ る。ただし, 日本人のヨウ素排泄濃度の個人間変動幅は 大きく，米国と比べて日本人の中には尿中排泄量が非常 に高いレベルの人の存在が確認された。これは, 海藻な どョウ素を高濃度に含む食品の摂取が日常的であること によるものであると考えられる。

諸外国に拈いては, これまで, スポット尿中ヨウ素に よるヨウ素摂取評価についていくつかの報告がある。 Andersen らは，デンマークのヨウ素の軽微な欠乏が疑わ れる地域の 15 名の男性を対象に，一年間に複数回のス ポット尿を採取し, スポット尿中ヨウ素濃度とクレアチニ ン濃度から推定した 24 時間尿中ヨウ素排泄量の変動を 調査した。その結果, 各対象者の 24 時間尿中ヨウ素排泄 量の年間平均值より算出した個人内変動は 20.1-70.5\% であるのに対し, 全対象者の 24 時間尿中ヨウ素排泄量の 年間平均值の平均值より算出した個人間変動は $27.0 \%$ であることを報告している（17）。この結果から，個人内
の日間変動は個人間変動を大きく上回る場合があること がわかる。一方で, Busnardoらのイタリアでの調査では, ヨウ素摂取が十分であるとされる地域に拈いて，男女 11 名を対象に 3 カ月間の期間中 2-3 日毎に食後午前中の スポット尿をサンプリングし，スポット尿中ヨウ素は個 人間変動 $(\mathrm{CV}=63 \%)$ に比べ個人内変動 $(\mathrm{CV}=36 \%)$ が 小さいことを報告している。同時にこの調査では，対象 地域でのヨウ素摂取源である牛乳，ヨウ素添加塩の摂取 の有無によって期間中の各人の複数のスポット尿中ヨウ 素濃度中央值に違いが見られたことから，複数回サンプ リング・測定した尿中ヨウ素濃度の中央值は，ある程度個 人の食の傾向を反映することを示唆している (9)。本研 究に扣いては, 全対象者 14 名の個人間変動 $(\mathrm{CV}=182 \%)$ に比べ個人内の日間変動 $(\mathrm{CV}=67 \%)$ は $1 / 3$ 程度であり, Busnardo らの調査と同様の傾向が見られたが，変動幅は Busnardo ら，Andersen らの報告に比べ個人内・個人間変 動ともに 2 倍以上大きく, 日本人の尿中ヨウ素濃度は個 人内・個人間ともに非常に大きな変動があることが確認 できた。

今回の調査では，ヨウ素を含有するらがい薬の使用者 1 名を含む 14 名の ICC は 0.55 であり, Rosnerらの解釈 では fair to good reproducibility $(0.4 \leqq \mathrm{ICC}<0.75)(14)$ に 該当した。この結果より, 対象者のなかに医薬品の使用 等によるヨウ素の過剰摂取者がいて個人間の变動が大き くなる場合には, 1 回の早朝尿を用いて個人間の習慣的 なヨウ素摂取レベルの差を検出することができるものと 考えられる。一方で，らがい薬による過唾摂取者を除い た 13 名では $\mathrm{ICC}=0.28$ となったことから, 数か月にわた るヨウ素摂取レベルの個人内変動は，ヨウ素長期摂取傾 向の個人間差よりも大きいといらことを示している。す なわち, 1 回の早朝尿を用いて対象者の長期的なヨウ素 摂取量レベルの個人差（ヨウ素含有食品の嗜好など）を 検出することはできないことが，統計的に示されたもの と考えられた。よって, 現在調査中である環境化学物質 曝露による妊婦の甲状腺機能への影響を介した小児発達 影響調査に打いて，長期的なヨウ素摂取状況による小児 の発達影響評価等に反映する指標として用いることは適 当ではないと判断した。しかしながら，採尿前日の「ヨ ウ素を高濃度に含むと考えられる食品等」摂取の有無に よって, 翌日の早朝尿中ヨウ素濃度に有意な差が得られ たことから (Fig. 2), 1 日程度の短期間でのヨウ素摂取 量評価指標としては，尿中ヨウ素濃度が有用であること を示すと考えられた。

近年のバイオマーカーを用いた環境化学物質曝露評価 の分野では, 生物学的半減期の短い物質について, スポッ ト尿を用いた ICC の検討がなされている。Teitelbaum ら は, ニューヨーク市内の 6 歳から 10 歳の健康なとスパ ニック・アフリカ系の子供を対象に, 約 6 カ月継続して 採取したスポット尿中化学物質を測定し，フタル酸エス テル類代謝産物やトリクロサンなどの生物学的半減期が 一日以内と考えられる化学物質でも ICC が 0. 35-0.62 で 
あることを報告している（10）。同様に, Suzuki ら（18） は，妊婦を対象に，スポット尿中フタル酸エステル類代 謝産物濃度を測定し，尿中代謝産物濃度は，フタル酸ジ エチル，フタル酸ジメチル，フタル酸ジェチルヘキシル などについて，約 2 カ月程度の長期的な曝露レベルを反 映した指標であることを ICC (0. 28-0.69) によって示し ている。

本研究対象のヨウ素は, フタル酸エステル類 $(<24$ 時 間 (19)) やトリクロサン（<4日（20） などと同様に代 謝が早く，摂取した殆どが 1 日以内に尿に排泄される (21, 22)。しかしながら, 環境化学物質と異なりヨウ素の 尿中濃度が長期摂取指標として適用できないという結果 となったのは，摂取源が異なることが原因であると考え られる。すなわち， ヨウ素は特定の医薬品を除き，食物 からの摂取が殆どであるが，フタル酸エステル類やトリ クロサンなどの環境化学物質は, 食物の他に, パーソナ ルケア製品 $(23,24)$ や室内空気 (25) など個人の生活習 慣に左右されやすい曝露源から摂取する可能性がある。 したがって，こうした個別性のある摂取源の有無によっ て，ICCの大きさが左右されたと考えられた。

\section{結 論}

日本人女性 14 名を対象として, 各人から繰り返し採取 した早朝尿中ヨウ素排泄濃度の測定値から，早朝尿中ヨ ウ素濃度は，前日のヨウ素摂取を反映する指標として有 用であることが確認できた。また，その尿中ヨウ素濃度 の個人間 - 個人内変動の解析結果から, 早朝尿中ヨウ素 濃度は，ヨウ素を含有する医薬品の習慣的使用等による ヨウ素過剰摂取者を検出する指標としては適用可能であ るが，過剰でない範囲内の，食品などからの日常的摂取 レベルに打りる個人間変動を検出する指標としては不適 であると考えられた。

\section{謝辞}

本研究にあたって尿サンプルの提供および質問調査に ご協力いただいた対象者の方々に深謝致します。

\section{文献}

(1) WHO, Iodine status worldwide: WHO Global Database on Iodine Deficiency. 2004.

(2) Delange F. The disorders induced by iodine deficiency. Thyroid. 1994;4:107-128.

( 3 ) Delange F. The role of iodine in brain development. P Nutr Soc. 2000;59:75-79.

(4) Vermiglio F, Lo Presti VP, Moleti M, Sidoti M, Tortorella G, Scaffidi G, Castagna MG, Mattina F, Violi MA, Crisa A, Artemisia A, Trimarchi F. Attention deficit and hyperactivity disorders in the offspring of mothers exposed to mild-moderate iodine deficiency: a possible novel iodine deficiency. J Clin Endocrinol Metab. 2004;89:6054-6060.

(5) ICCIDD, Excessive Iodine Intake: A short guideline. Hans Burgi for the ICCIDD Science and Technology Committee, 2007. http://www.iccidd.org/pages/technical-resources.php.

(6) Roti E, Uberti ED. Iodine excess and hyperthyroidism. Thyroid. $2001 ; 11: 493-500$.

( 7 ) Nishiyama S, Mikeda T, Okada T, Nakamura K, Kotani T, Hishinuma A. Transient hypothyroidism or persistent hyperthyrotropinemia in neonates born to mothers with excessive iodine intake. Thyroid. 2004;14:1077-1083.

（8）厚生労働省. 日本人の食事摂取基準．2010 年版.

( 9 ) Busnardo B, Nacamulli D, Zambonin L, Mian C, Piccolo M, Girelli ME. Restricted intraindividual urinary iodine concentration variability in nonfasting subjects. Eur J Clin Nutr. 2006; 60:421-425.

(10) Teitelbaum SL, Britton JA, Calafat AM, Ye X, Silva MJ, Reidy JA, Galvez MP, Brenner BL, Wolff MS. Temporal variability in urinary concentrations of phthalate metabolites, phytoestrogens and phenols among minority children in the United States. Environ Res. 2008; 106:257-269.

(11) Niwa M, Suzuki Y, Yoshinaga J, Watanabe C, Mizumoto Y. Prenatal exposure to polycyclic aromatic hydrocarbons and birth outcomes. Polycycl Aromat Comp. 2011;31:1627.

（12）文部科学省．日本食品標準成分表．2010.

(13) Bonses RW, Taussky HH. On the colorimetric determination of creatinine by the Jaffe reaction. J Biol Chem. 1951; 158:581-591.

(14) Rosner B. Fundamentals of biostatistics, 6th ed. CA: Duxbury; 2006

(15) Orito Y, Oku H, Kubota S, Amino N, Shimogaki K, Hata M, Manki K, Tanaka Y, Sugino S, Ueta M, Kawakita K, Nunotani T, Tatsumi N, Ichihara K, Miyauchi A, Miyake M. Thyroid function in early pregnancy in Japanese healthy women: relation to urinary iodine excretion, emesis, and fetal and child development. J Clin Endocrinol Metab. 2009; 94 : 1683-1688.

(16) Caldwell KL, Jones R, Hollowell JG. Urinary iodine concentration: United States National Health and Nutrition Examination Survey 2001-2002. Tyroid. 2005; 15:692-699.

(17) Andersen S, Perdersen KM, Pedersen IB, Laurberg P. Variations in urinary iodine excretion and thyroid function. A 1 -year study in healthy men. Eur J Endocrinol. 2001;144: 461-465.

(18) Suzuki Y, Niwa M, Yoshinaga J, Watanabe C, Mizumoto Y, Serizawa S, Shiraishi H. Exposure assessment of phthalate esters in Japanese pregnant women by using urinary metabolite analysis. Environ Health Prev Med. 2009; 14: 180-187.

(19) Schmid P, Schlatter C. Excretion and metabolism of di(2ethylhexy1)-phthalate in man. Xenobiotica. 1985;15:251256

(20) Sandborgh-Englund G, Adolfsson-Erici M, Odham G, Ekstrand J. Pharmacokinetics of triclosan following oral ingestion in humans. J Toxicol Env Heal A. 2006;69: 1861-1873.

(21) Rasmussen LB, Ovesen L, Christiansen E. Day-to-day and 
within-day variation in urinary iodine excretion. Eur J Clin Nutr. 1999; 53: 401-407.

(22) ICRP. ICRP Publication No. 78. Individual Monitoring for Internal Exposure of Workers. Replacement of ICRP Publication 54, Annals of the ICRP 1997;27(3-4)

(23) Duty SM, Ackerman RM, Calafat AM, Hauser R. Personal care product use predicts urinary concentrations of some phthalate monoesters. Environ Health Perspect. 2005; 113:
1530-1535.

(24) Allmyr M, Adolfsson-Erici M, McLachlan MS, SandborghEnglund G. Triclosan in plasma and milk from Swedish nursing mothers and their exposure via personal care products. Sic Total Environ. 2006;372:87-93.

(25) Otake T, Yoshinaga J, Yanagisawa Y. Exposure to phthalate esters from indoor environment. J Expo Anal Environ Epidemiol. 2004; 14:524-528. 